\title{
Ritual and the Social Meaning and Meaninglessness of Religion
}

\author{
Von Daniel B. Lee
}

Sociologists, along with most other people, typically describe religion as if it was comprised of two corresponding components: beliefs and rituals. According to this line of reasoning, the members of a religious community share beliefs about the sacred and enact those common beliefs in their rituals. From this traditional and rationalist perspective, it makes sense to assume that action is always motivated by thoughts or beliefs. Thus, if one observes the performance of a ritual, one may take for granted the preexistence of motivating beliefs. In this paper I argue that the successful enactment of ritual is highly improbable and gains no support from subjective beliefs. I also suggest that it is impossible for participants in ritual to share common beliefs or intersubjectivity. Individuals may collectively perform a ritual without attaching the same belief, or any belief, to it. Sociologists cannot assume that religious beliefs and rituals necessarily have any correspondence. I conclude by suggesting a theory of ritual that accentuates the difference between conscious and social systems of meaning.

Following Emile Durkheim, contemporary sociologists of religion generally suggest that beliefs and rituals are the two most important components of religion (Yinger 1965, p. 9; Schneider 1970, p. 6; Roberts 1990, p. 21; Chalfant/Beckley/Palmer 1994, p. 29; Berger 1990). Durkheim maintained that »every religion is made up of intellectual conceptions and ritual practices, « of beliefs and rites (1954, p. 121). »Religion pervades the whole social life, « he believed, »because social life is made up almost exclusively of common beliefs and of common practices which derive from unanimous adhesion a very particular intensity« (ibid., p. 178).

Durkheim explained that during the religious ritual, members of a community come to recognize the power of their union, creating a special mood of »collective effervescence.« Durkheim suggested that rituals are the enactments of collectively held beliefs, but that rituals create the shared ecstasy required for the formulation and »unanimous « affirmation of those beliefs. Because the power of collective effervescence is so essential in the production of social solidarity, Durkheim argued that:

»There can be no society which does not feel the need of upholding and reaffirming at regular internals the collective sentiments and the collective ideas which make its unity and its personality. Now this moral remaking cannot be achieved except by the means of reunions, assemblies and meetings where the individuals, being closely united to one another, reaffirm in common their common sentiments (...).«(1954, pp. 474-475)

While he did not primarily focus on ritual, Max Weber and his students tend to emphasize the notion that members of religious groups share a human need for metaphysical beliefs: that is, for meaningful interpretations of reality. Prophets, philosophers, and intellectuals create interpretations that may be adopted by followers. Priests systematize and consolidate popularly embraced religious insights into creeds and organize congregations of believers who »carry« culture. Believers use symbols during religious rituals to »stabilize« a shared meaning of reality (sinnhafte Deutung der Wirklichkeit). Weber noted that rituals are controlled, rule-oriented procedures that gain in holiness by »stereotyping « themselves without change. Religious beliefs achieve practical results, in Weber's assessment, helping adherents succeed at life. Beliefs satisfy believers by helping them cope with uncertainty, temptation, misfortune, inequality, sickness, guilt, and death (Weber 1958; 1963; 1980). In this paper, I cannot devote adequate attention to describing Durkheim or Weber's sociology of religion. However, I want to make the point that both pioneering sociologists of religion assumed the possibility of intersubjectivity (or in Durkheim's formulation: collective representations, col- 
lective conscious): religion attains social meaning due to shared beliefs. Weber's concept of »intersubjective« meaning has been elaborated, among others, by Alfred Schütz (1967), Peter Berger and Thomas Luckmann (1966), and Jürgen Habermas (1984). In Niklas Luhmann's summary, »The sociology of religion, from Simmel to Luckmann, has always related religion to subjective consciousness and thereby presumed an itself self-conscious consciousness « (2002a, p. 29). Luhmann argues that the concept of intersubjectivity is the product of theoretical confusion, a Verlegenheitsformel that suffers from a severe disadvantage: it has trouble indicating the unity of what it hopes to mean (1995a, pp. 169, 172).

As they are generally opposed to psychological approaches, it seems remarkable that so many sociologists who study religion should put so much importance on the personal beliefs of individuals - as if the social meaning of a ritual depended on what people understood it to mean. Ritual is socially meaningful as a demonstration of social solidarity because it transcends the personal beliefs of individuals. To be socially meaningful, religion does not have to mean anything to anybody. If the members of a group see themselves enacting a ritual, they may assume that they share religious belief, an assumption that can certainly enhance the impression of being socially integrated (Thomas Theorem). They do not, however, need to share any common beliefs in order to enact the ritual successfully.

Enacting ritual requires participants who know the right moves, possess the props, and can make the expected noises at the right moments: regardless of what they may believe. As an operation, ritual becomes socially significant when it reproduces itself in a perceptible, immanent, and redundant form. The form of the ritual is closed and precludes spontaneity and freedom. Whatever meaning participants consciously attach to their real-time behavior, the ritual either simulates its expected form, or else it does not. The cultivation of a repeatable and recognizable ritual - the bundling of successive selections from among a vast horizon of behavioral possibilities and routines - should not be expected to happen. There are so many different things participants can do: why should they bind themselves to the rules of the ritual? Ritual can happen only when participants restrict their behavioral possibilities in a socially ordered manner that is neither necessary nor impossible. To beat the odds against its happening, ritual must be coordinated by communication, not by thoughts.

My rejection of the established viewpoint, that the actors of a ritual necessarily share religious beliefs, is supported by my observations of rituals enacted by members of the Weaverland Conference Old Order Mennonites (Lee 2000). Individual Mennonites may indeed hold personal beliefs, but any alleged beliefs remain locked up in each member's mind: operationally closed to Mennonite Society and any other observers. Ministers, bishops, brothers, sisters, and sociologists cannot perceive the religious beliefs of others. Thoughts (beliefs) can only make meaningful differences to conscious systems; they cannot meaningfully inform social systems (Luhmann 1995b; 2002b; Fuchs 2004). In this paper, I describe how members of this community successfully enact the rituals of foot washing, baptism, expulsion, and reconciliation without a common understanding of what the rituals are supposed to signify or why they are meaningful. Old Order Mennonites assemble and ritualistically »uphold and reaffirm common sentiments « that individual members do not believe or even understand.

\section{Rituals of the Old Order Mennonites}

The social life of Weaverland Conference Old Order Mennonites is strictly regulated by a normative code known as the »Discipline, « which symbolically marks the community's boundary. The Discipline, sometimes called the »Conference Rules « or »the Ordnung, « explicitly lays out standardized behaviors, prescriptive and proscriptive norms, with which members must conform or be expelled from the group. The Discipline, for example, prescribes what kind of automobile members may drive. All vehicles must be »in black color, (ha- 
ve) no stripes, nor (have) flashy trimmings « (Hoover 1982, p. 698). Because of their black vehicles, members of this church have been called »Black Bumper Mennonites.« Members claim that adherence to the behavioral regulations of the church keeps them from becoming integrated with »the world. « Mennonite practices are anchored in tradition and are followed because »that is just the way we do it. « Working on Sundays, using a radio, watching television, joining political parties, wearing cosmetics, purchasing insurance policies, and driving sports cars are other things prohibited by the Discipline. It is the Discipline that also mandates that men wear black hats, black suits, and white shirts to church. Women wear white head coverings and dresses of the same length and style, with long sleeves and attached aprons.

\section{Footwashing}

One of the most important rituals practiced by Mennonites is exchanging the »kiss of peace« after observing communion and footwashing. The Confession of Faith of the Mennonite (COF), a little black book given to all members at the time of baptism, precisely describes how the kiss ought to be performed:

Then both shake hands with each other and give each other the kiss of peace, whereupon the one says:

»The Lord will preserve and strengthen us in love«; the other says »Amen.« (COF 1996, p. 56)

After watching Mennonites perform this ritual for the first time, I was curious to know what they whispered to each other after exchanging the kiss. After church I asked an older man what was said. He explained, »we always say the same thing: one of us gives a greeting and the other says >amen.< The words of the greeting are important, they are: >May the Lord guard, guide, and direct you.« «I inquired how the two decide who will give the greeting and who will say »Amen.«»That's easy, « the man replied, »the one who had his feet washed first says the Amen.«

I walked over to another member and inquired about the words exchanged. Once again, it was claimed that »everyone says the same thing, a greeting and an amen.« However, this time the words of the greeting were different: »May the Lord love and protect you.«

$»$ Amen.«

After I interviewed a third member of the church about the words used in the greeting, the reason for the different responses became clearer:

Author: After members exchanged the »kiss of peace, «I saw them lean over and whisper into each other's ears. Can you tell me what was said?

Member: Well, one says the greeting and the other says »amen.«

A: What kind of greeting is it? Does everybody say the same thing?

M: Everyone says the same thing.

A: Can you tell me what words are used?

M: Yes... We say, »May the Lord... (mumbles something).« Like that, then the other says »Amen.«

A: I'm sorry, I didn't hear the words of the greeting. What are they again?

M: You just have to say »May the Lord... (mumbles), « you know. Then the other says »Amen.«

A: But, David, what are the exact words used in the greeting?

M: I'll tell you the truth (smiling). We are supposed to say the same thing, but I don't really know the exact words. I just say »May the Lord...« and mumble something. I know most of the guys don't really know what to say. They never told us exactly what to say. The important thing is to make it look right.

Since members are supposed to study their personal copy of the Confession of Faith of the Mennonite, they should all know the exact wording of the »correct« greeting. Yet they do not know. The important thing, it seems, is to »make it look right. « When asked about the re- 
ligious significance of the »kiss of peace, « members of the church were almost always prepared to give an explanation, but an explanation tainted with idiosyncrasy:

- Our ancestors brought the kiss with them from Germany and Switzerland. We want to hold on to those traditions.

- The kiss was established by the early leaders of the church. Mennonites just believe in doing it.

- It's from the Bible. The disciples did it.

- It's something we have always done.

- I don't know why we do it.

Mennonites and Amish will actually give one another the Holy Kiss even if they have strong personal feelings against the practice. The following letter to the editor of an Old Order periodical is illuminating. This letter was published in Family Life, a journal widely read among the Mennonites I observed. The author of the letter complains about having to give the kiss to his brethren and confesses that he attaches no spiritual significance to the kiss:

Holy kissing makes many miserable (...). It's so repulsive! That spit spot on the lips and that irresistible urge to wipe off one's mouth with the back of your hand first chance he's not looking, is anything but a feeling of holiness. It's so germy and unsanitary. Glasses often clack together. Often on cold days it's not just spit on the lips but catarrh or nose drip on the cheek. I'm not trying to be sarcastic! (Family Life Feb. 1984, p. 3)

The author concludes his letter by arguing that the church should do away with the holy kiss as traditionally practiced. Until this happens, however, we may be certain that members will continue to exchange the kiss of peace whether or not they »believe« in the custom.

\section{Baptism}

When they are about fifteen years of age, girls and boys in the Mennonite community usually request to be baptized. Even if one was born into the community, membership in the church begins with the ritual of baptism. The girls and boys tend to go through the baptismal process as a group or »class. «It would be irregular for a person to not be baptized along with his or her age cohort. Baptisms generally occur during the »Fall Preparatory Service, « after the young people have attended »Instruction Meetings. « During these meetings, which »begin the last Sunday afternoon in July at two o'clock, « the young people »study« the First Part of the Confession of Faith booklet. The First Part of the little black paperback contains the »Eighteen Articles of the Dortrecht Confession of Faith, « adopted by Anabaptist ministers in 1632. At each meeting for instruction, three of the Articles are read aloud to the $\gg$ applicants.« The Confession of Faith booklet clearly indicates how the instructional meetings are to proceed:

Applicants will sit near the preachers' table, with the boys on the men's side and the girls on the women's side. The ministry come in the same door as the others. Services begin by singing two hymns, followed by a short, opening message by a minister, and then a kneeling, silent prayer. Three ministers will each teach one of the eighteen articles, followed by testimonies. The minister who taught last will lead in a kneeling, audible prayer, closing with two hymns and a benediction. (COF 1996, p. 45)

After the Ninth Article has been explained, and once again at the last instruction meeting, the bishop asks the class »if they are satisfied with the teaching they have received. « The last three Articles of the Dortrecht Confession are read »on a Friday afternoon at two o'clock, « with only the applicants and the ministry in attendance. At this last meeting, the boys wear dark suits and the girls wear dark dresses, preferably navy blue. In order to be baptized during the Preparatory Service, each individual applicant must have attended all of the Instruction Meetings and been approved by the congregation at the Counsel Meeting. 
Baptism is an outward testimony of an inner New Birth experience, and Baptism shall be administered upon a confession of one's faith and repentance toward God. (COF 1996, p. 47)

Wearing dark clothing, the applicants bow on their knees in front of the membership to make their three »baptismal vows. « The complete vows, as pronounced by the bishop, are as follows:

The first question of the baptismal vows is; »Do you believe in one almighty God who hath created heaven and earth - all things visible and invisible and preserves the same by His power; and do you believe in Christ Jesus, His only begotten Son, who was conceived of the Holy Spirit and born by the pure virgin Mary, suffered under Pontius Pilate, died on the cross, was buried in a sepulcher, arose victorious the third day, and after forty days ascended into heaven to the right hand of God, from whence he will come again to judge the living and the dead; and do you believe in the Holy Spirit who proceeds from the Father and the Son, to chasten the world because of sin, and that you have become willing to be baptized by the guidance of the same. Can you answer this with >Yes $<$ ?

Secondly, you are asked, are you sorry for your past sins and are you willing to renounce Satan and the dark kingdom of this world, your own will and all the satanical works of this world. Are you willing to be subject to the Gospel of Christ Jesus, to have the same rule in and over you as much as God grants you grace. Can you answer this with $>$ Yes $<$ ?

Thirdly, are you willing to submit to the Gospel of Jesus Christ, especially Matthew the 18th Chapter, where it says, >If thy brother shall trespass against thee, go and tell him his fault between thee and him alone; if he shall hear thee thou hast gained thy brother, but if he will not hear thee, then take with thee one or two more that in the mouth of two or three witnesses every word may be established. And if he shall neglect to hear them, tell it unto the church, let him be unto thee as a heathen man and a publican.< Are you willing to have this used against you and help use it against others as necessity may demand. Can you answer > Yes<. (COF 1996, pp. 49-50)

After the applicants have affirmed these vows, the bishop kneels with them in prayer, closing with a solo recital of the Lord's Prayer. The bishop then rises and steps before each kneeling convert, one at a time, with his hands laid upon their uncovered heads he says:

Upon thy confession of faith, which thou hast confessed before God and many witnesses, thou art baptized with water, in the name of the Father, and of the Son and of the Holy Ghost. (COF 1996, p. 51)

When the bishop says the words, »baptized with water, « to each convert, the deacon pours a small amount of water on top of the new member's head.

When all are baptized, the bishop then approaches the first baptized person and extends him the right hand of fellowship and says, »In the name of the Lord, in the name of the church, I offer thee my hand; arise, to a new beginning, to a new life. The Lord strengthen you that you may be able to finish your newly started work, and be his disciple; acknowledge the truth and the truth shall make you free.«(COF 1996, p. 51)

As a conclusive sign of acceptance, the bishop exchanges the »kiss of peace « with each of his new brethren. The bishop's wife greets each of the new sisters with the same sign. The new members are then asked to be seated and the service continues to the end.

Immediately before joining their church through baptism, as I have already related, the applicants for baptism participate in a mandatory program of »instruction.« For nine weeks, they meet after Sunday services with members of the ministry. During each session, two articles of faith from the Confession of Faith of the Mennonite (1996) are read aloud. There is very little discussion about the meaning of each article of faith and no formal attempt is made by the ministry to test whether or not students have understood or memorized the articles of belief. It is assumed, however, that the young adults who join the church have adopted the confession that Mennonites are expected to share.

Calvin Redekop conducted an investigation of Old Colony Mennonites in Mexico and observed how young people were »taught « what members of the church ought to believe. Re- 
dekop also intimates that young people who desire to join an Old Colony congregation must study their group's beliefs well enough to pass a ceremonial review:

When the applicants have successfully »understood « the catechism, they are presented to the congregation on a Sunday morning. The minister asks them to rise and answer in order the questions studied in class.

The object of the ceremony is to recite his answers flawlessly. For the congregation, the object is to see how well the applicants have learned their catechism. »The saying of the catechism is the very important event. It is the thing the young people dread most. Most young people memorize it by rote, not knowing what is going on as far as meaning is concerned.« (Redekop 1969, p. 58)

Among both the Weaverland and Old Colony Mennonites, each baptismal applicant is expected to openly confirm his or her willingness to accept their group's religious doctrine. Through the ritual of baptism, each individual communicates his or her willingness to accept the collective »Confession of Faith.«Even if members do not understand the meaning of the articles that comprise the official confession, they can publicly affirm that they accept the collective beliefs of their congregation.

\section{Expulsion and Reconciliation}

Members who transgress against the rules established in the »gospel and the regulations of the church « and who do no not repent of their sins are »expelled « from the Weaverland Church until they do so. Members believe that the Bible teaches them to separate themselves from »disorderly« people:

If a member falls into gross sin or is not willing to be admonished in errors in his way of life, he shall be excomunicated from the church. When he shows repentance and amendment of life, and wishes to be reinstated again in the church, he will make his desire known by coming into the minister's room on a Sunday morning and presenting his application to the ministry, who then presents it to the congregation. The bishop will take counsel with the church concerning reinstating him. (COF 1996, p. 60)

The Weaverland manner of excommunication is not as complete as the »shunning « performed by the Old Order Amish. Regarding the Amish practice, Kephart and Zellner reported the following:

The ultimate sanction is the imposition of the Meidung, also known as the »shunning « or »ban, « but because of its severity, it is only used as a last resort. The followers of Jacob Amman have a strong religious orientation and a finely honed conscience - and the Amish community relies on this fact (...) The ban is total. No one is permitted to associate with the errant party, including members of his or her own family (...) Should any member of the community ignore the Meidung, that person would also be placed under the ban. (1994, p. 27)

In contrast, »expelled « Weaverland Mennonites are permitted to attend worship services with their families and may even participate in social activities. It is, nonetheless, strictly forbidden to allow expelled members to participate in the religious »ordinances « (foot washing, holy kissing, communion, council). It is not uncommon for officially excommunicated members to continue to attend church services.

If a member must be expelled, which is seldom the case, the Bishop announces his or her name and the practice that is considered intolerable in front of the assembled congregation. From the moment the ban is instituted, it is hoped that the experience of expulsion will encourage the detached person to find his or her own way back into the realm of authentic membership. If the expelled person decides to mend their ways and rejoin the church, he or she must ask the bishop for the opportunity to ask forgiveness in front of the assembled congregation.

At the end of a normal Sunday worship service, I observed this ritual of reconciliation to proceed as follows. After leading the congregation in prayer, the bishop announced that an 
expelled person, mentioned by name, desired to confess his sins and request membership in the church. He then exchanged glances with a man standing in the back of the men's section. This man came forward and met the bishop in the center of the building, in front of the entire congregation. The expelled man stood directly in front of the bishop with his hands clasped tightly at the waist and eyes cast to the floor. The bishop inquired in a loud voice, »Do you answer with yes that you have repented of your sin? « With a very brief look upward, the man whispered »yes. « »Do you answer with yes that you have asked God to forgive you and that He has done so? «»Yes. « The bishop seemed to refrain from looking directly at the man, preferring instead to observe the congregation. Most of the members had their heads bowed. The bishop continued, »Because you have repented and been forgiven you are once again a member of the church. The ordinances of communion, foot washing, and council are restored to you. « The bishop then clasped the other man's hand and gave him the kiss of peace on the lips. After this ceremony, the two men sat down and the songleaders led the church in singing two hymns about forgiveness and mercy.

The procedural rules dictating how the congregation must receive an expelled member who repents of breaking the Discipline are codified in the Confession of Faith (1996). It is essentially the same procedure that bishop Jonas Martin, the first leader of the Weaverland Conference, followed nearly one hundred years ago (Hoover 1982, pp. 701-709).

After observing the church perform this ritual of reconciliation for the first time, I asked members after the service to describe what the expelled man had done. I was startled by the variety of answers received. One member replied, »Oh, he was a drinker.« Another reported, »Henry cheated on his wife.«A third informant answered with, »That man went with women for money. «Still another member simply replied that she did not remember what the man had done, »After all, he was expelled almost a year ago.« Each time a member is expelled, the bishop is required to make the reason for expulsion completely clear, revealing the nature of the sin in front of everyone present. Even though he must do this, it seems evident that members do not feel it is important to specifically know or remember what a »disorderly person « did. In fact, during the ritual of reconciliation, nobody seems to demonstrate much interest in the interaction between the bishop and the one seeking reconciliation. Apparently, the important thing is that all members remain aware of the Regulations of the Church and conform to them.

\section{The Social Meaning of Rituals and Beliefs}

While rituals such as baptism, expulsion, and reconciliation emerge as actual events that can be observed, both by members and visiting sociologists; the beliefs that participating actors consciously attach to such practices remain extrasensory. Outside of consciousness, there is no medium in which the presence, absence, or quality of a belief could make a measurable or informative difference. As Peter Fuchs suggests, »Communication may select the occurrence of consciousness as a theme, but it can have no access to any single empirical consciousness « (2004, p. 84). Subjectivity is operationally closed to society. Though there can be no sociology of the inner religious experience, several significant questions may still be entertained. First, in the absence of intersubjectivity and other forms of mental telepathy, how are social rituals coordinated? Second, how and under what conditions does society develop religious beliefs as a theme? Finally, how can sociology make sense of the difference between rituals and the beliefs of participants?

The religious conduct of Mennonites is governed - directed, guided, and regulated - by the rules described in the Confession of Faith booklet and the behavioral codex known as the »Discipline.« According to Anthony P. Cohen (1985, p. 16), »When we speak of people acquiring culture, or learning to be social, we mean that they acquire the symbols which will 
equip them to be social.«Symbols, Cohen maintains, »do not tell us what to mean, but give us the capacity to make meaning. « For the construction of a plausible community, members depend on rituals and symbols for the simple reason that their own personal beliefs, because they are closed to society, cannot »equip them to be social.«Rituals, like dances, parades, dramas, and boxing matches, are symbiotic relations in which humans coordinate a series of selections about how to display their body. Accommodating their own choices to the closed rules of ritual, participants can make meaningful impressions on one another and simulate the reality of the group. As long as members accommodate themselves and contribute to a »good show, « the ritual will successfully contribute its own meaning.

Thoughts cannot broach the limits of consciousness, but bodies can be mutually controlled so that members can meaningfully participate in ritual. Thus, communication about rules reproduces ritual, as when Mennonites write and read and understand the Confession of Faith book. More than any other structural resource, this small book helps coordinate each of the Mennonite rituals by plainly stating what each participant must do during the performance. When reconstructing a specific ritual in actu, participants accommodate themselves to behavioral schemes consciously understood during the course of previous communication about rituals. Participants learn what others expect to see them do and say by reading the COF, imitating the performance of older members, and from personal trial and error. Participants who make »mistakes « or intentionally slip from the frame during live performances encourage additional socialization by irritating the expectations of others and triggering »contingency communication « (Fuchs 2004, p. 22). Only communication may determine the contingent operating procedure required to simulate a certain ritual. Were intersubjectivity a possibility, believers could still not perform a ritual without first learning the rules and accommodating their behavior. Ritual does not integrate minds; it calibrates bodies.

Despite the certainty of its own operational closure, under what conditions does society take up religious beliefs as a theme? With respect to beliefs, if society cannot make a difference on consciousness, how can it make a difference on itself? Before attempting to unravel this theoretical issue, let us briefly reconsider the case of Old Order Mennonites.

We have already concluded that, for Mennonites, maintaining correct and uniform ritual order and outward discipline (orthopraxis) appears to be more important than cultivating communication about correct beliefs and doctrine (orthodoxis). Mennonites learn how to follow the church Discipline and what happens to those who do not; but members are seldom taught why they ought to conform to the rules or how to account for the significance of each ritual (Lyman/Scott 1968). The unspecialized, volunteer, part-time organizational leaders of the church make no concerted effort to instruct members as to why they should adhere to the Church's rules. They do not attempt to monitor whether or not members of the church hold »correct and proper« Mennonite beliefs, not even as a preliminary test before baptism. The church prohibits Sunday school, seminary, and general education after the eighth grade. There are no organizational opportunities in which Mennonites expect one another to freely participate in communication about religious ideas, testing the variance and degrees of freedom; confronting and conditioning double contingency (Luhmann 1995b, pp. 133-134). Weaverland Mennonites in New York State do not make a habit of reading and discussing their Confession of Faith book, they do not evangelize or formally teach doctrine, and they do not openly discuss one another's beliefs. Mennonite communication does not choose to condition the beliefs of Mennonites. Therefore, the accommodation and assimilation of members to a particular program of orthodoxy is minimal. The viability of a Mennonite as a member in good faith is tested on the basis of practice. Mennonite society depends on rules and rituals to seal its boundary and reify programs of community, humility, simplicity, and discipline. As John Hostetler observes with regard to the Old Order Amish, it is more important to live the faith than to be able to explain it (1993). 
Orthodoxy does not exist until it is created, and the process of cultivating the theme and description of a complex and contingent theological program is tedious. A »correct « belief would have to be invented, articulated, adopted, disseminated, and constantly protected against alternative beliefs (Zito 1983). Despite the effort involved, a religious organization might decide to cultivate orthodoxy when its members begin to express an adequate amount of »noise « (von Foerster 1960). In other words, if members began to speak about beliefs and make an effort to sound each other out, it is likely that disagreement, confusion, and irritation would result from the exposure of double contingency. Members who gloss over their beliefs and do not test each other's assumptions have an easier time taking consensus for granted. At this point, the sociological investigation takes an evolutionary focus: how and under what conditions does communication differentiate and unify religious beliefs and practices?

The noise created as members attempt to straighten out the variety exposed by communication threatens the imaginary unity of the organization. How can members believe in their unity if communication continually reproduces uncertainty about the difference between correct and false beliefs? Those most irritated by the noise may attempt to silence it by structuring communication, adding complexity in the form of orthodoxy and hierarchy, and destroying variety with variety (Ashby 1957). Role players (ministers, deacons, bishops) may be differentiated and placed »in charge « of deciding who can speak with authority about the church's beliefs. Specialists may assemble propositions into a creed and then organize ritualistic displays of instruction, inquisition, and confirmation. Organizational authorities tend to select and »certify « religious propositions in order to end communication about alternatives. This closing down of possibilities is required before an organization can open itself to the assumption of orthodoxy. Conflict about beliefs has an immunizing function: it stimulates an increase in the complexity of communication about what does not fit the established program, about what is foreign and what must be destroyed (Luhmann 1995b, pp. 369-373). Though it involves a political question of binding power, unbelievers, heretics, apostates, free thinkers, and other noise makers can be denied an address in the community of the saints. No address: no communication. Well known historical incidences of excommunication during the Reformation and Enlightenment demonstrate, however, that communication is capable of drawing its own boundaries.

Members of a church may assume that they believe the same things, and they may even endeavor to establish an orthodox creed and require affirmation to it. A heretic, however, may also be compelled to affirm the official creed. Spies and traitors can pledge allegiance to the flag. People may stand together and recite a creed or pray in a language that they do not understand. I repeat: a symbol or ritual may be personally meaningless and still have meaning for society.

Certain social conditions appear to increase the likelihood of noise and subsequent attempts to systematize creeds and their acceptance rituals. Insiders may be asked to account for their beliefs by outsiders. For instance, Mennonites who migrated from Pennsylvania to settle in New York State are more likely to have neighbors who are unfamiliar with Old Order customs and habits. More frequent communication with curious neighbors can produce an increased appetite for religious semantics: how do I explain to my neighbor that Christians should only own black cars? Apart from interaction with »the world, « the evolution of communication forms may also increase noise and attempts to regulate it. When Mennonites decide to hold services in English because too few members understand German, the increased level of comprehension among insiders can result in noise. When an organization distributes printed texts to members, noise may be a consequence. Any effort to increase the educational level and literacy of members would be likely to increase the number of random perturbations. The appearance of prophets and those who are spiritually entranced (connec- 
ted to God) may also contribute noise, at least as long as communication can make some initial sense of revelation.

From a sociological perspective, Mennonite communication and the consciousness of each Mennonite are co-productions that condition each other. The difference between ritual and belief cannot be denied, as it creates the possibility for a Mennonite social system to come into view. Communication cannot create its own meaning, and neither can consciousness. As Peter Fuchs explains: An observer who concentrates on observing consciousness will not find any idiosyncratic meaning because he could not understand it. This does not deny the possibility that a consciousness may process idiosyncratic meaning; but only asserts that at the moment it attempts to securely grasp it (yet to convey it), it can only make use of ready made, previously available social meaning (2004, p. 42-43).

Communication necessarily entails the availability of conscious systems who remain operationally closed to one another, but who can observe meaningful differences made with the selective use of signs. To have social meaning, a ritual may not be owned by any single interpreter. As the structural couplings that enable communication, signs (and rituals) only inform those who refuse their possession.

Rituals are socially meaningful because they demonstrate in a perceptible manner the interpenetration of consciousness and social system. If the self-referential rules of ritual are followed, properly self-conditioned participant/observers may successfully connect each successive operation to others, consciously synchronizing operations to form a recognizable unity. As a social system, Mennonite communication reproduces itself by making itself available to the perceptions of conscious participants. In the end, the self-referential form of a ritual remains open to conditioning by participants who engage in communication about how they believe rituals should be conducted (and here is where the need to change rules can become a theme). But such beliefs cannot emerge as beliefs; they can only take form within the flow of communication.

\section{Conclusion: Toward a Theory of Ritual}

A ritual is an imaginary performance pattern for coordinating and synchronizing the display of human bodies and other selected objects during scheduled real-time interactions. Society constructs the performance pattern of a ritual as a solution to the problem of how participants can coordinate spontaneous displays without sharing consciousness. Ritual destroys the variety of possible human behavior by restricting spontaneity; it is the conscious attempt to socially organize a series of spontaneous selections. The complexity of ritual increases as the possibilities for meaningfully displaying bodies is reduced by society in a selected manner that is possible but not necessary.

As first order observers, participants in ritual have learned to expect one another to limit themselves to simulating a performance pattern established in communication. The distinction between a viable performance and a failure is marked by a second order observer, who may also be a performer. The expectations of second order observers are conditioned by their participation in communication about ritual. In ritual, meaningful displays are redundant and conform to the performance pattern suggested by communication. One circumambulates, one genuflects, one chants, one eats, one gives a kiss, one spits at Satan: one performs each display as a distinct operation. Communication suggests meaningful connections between discrete ritual operations, preparing observers to expect to perceive a contingent series of recursive displays. Second order observers (including participants) perceive the display of bodies and objects and consciously process their fleeting impressions with respect to an imaginary self-referential and self-constructed form of ritual. 
The form of ritual may be described as a primary distinction with two sides (see SpencerBrown 1969): expected display/unexpected display. A viable ritual is recognized by cultured observers as a familiar unity in difference, a perfectly continuous reproduction on the side of »expected displays. " This self-referential unity represents the social system in operation. Due to the operational closure of both consciousness and communication, participants in ritual cannot attach their thoughts to ritual in a socially meaningful manner. Conversely, society cannot restrict or govern the thoughts of participants. However, both consciousness and communication may select ritual as an intended theme. Conditioned observers of ritual may miss an expected scent, anticipated sound, or predicted touch. They may see someone drop a prop, skip a step, appear in the wrong costume, or forget their lines. Cultured observers who perceive such unexpected displays or omissions may become irritated enough to participate in additional communication about ritual, which may further condition the expectations of observers. Ritual cannot perceive its own expected displays, and consciousness cannot prepare itself to make sense of what the senses perceive.

In the mind and heart of an individual person, religious rituals may »mean « a great deal. It is easy to accept that a person may feel strongly about the significance or meaning of a particular ritual. Nonetheless, religious beliefs are socially meaningless (they can make no difference in society) because a human community, having no spirit or mind, cannot possibly hold them. Despite its longstanding appeal among sociologists of religion, intersubjectivity is not a scientifically valid or useful hypothesis because its existence cannot be verified or falsified. Any attempt to operationalize intersubjectivity as a variable would require telepathy. Sociologists cannot read minds any better than the faithful. Even without the existence of a collective consciousness, however, rituals remain socially meaningful because they have the symbolic power to associate, coordinate, and calibrate individuals in a visible, external, and predictable manner. This power is the result of successful communication. 


\section{Literatur}

Ashby, Ross W. (1957): An Introduction to Cybernetics, London: Chapman and Hall.

Berger, Peter (1990): The Sacred Canopy. Elements of a Sociological Theory of Religion, New York: Anchor.

Berger, Peter/ Luckmann, Thomas (1966): The Social Construction of Reality. A Treatise in the Sociology of Knowledge, New York: Anchor.

Chalfant, Paul H./ Beckley, Robert E./ Palmer, Eddie C. (1994): Religion in Contemporary Society, Itasca: Peacock.

Cohen, Anthony P. (1985): The Symbolic Construction of Community, New York: Tavistock.

Confession of Faith of the Mennonites, COF (1996): Published by the Weaverland Conference.

Durkheim, Emile (1954): The Elementary Forms of the Religious Life, New York: Free Press.

Family Life. Feb. (1984).

Foerster, Heinz von (1960): On Self Organizing Systems and Their Environments, in: Self Organizing Systems, edited by Marshall C. Yovits and Scott Cameron, London: Pergamon, pp. 31-50.

Fuchs, Peter (2004): Sinn der Beobachtung, Weilerswist: Velbrück.

Habermas, Jürgen (1984): The Theory of Communicative Action, Boston: Beacon Press.

Hoover, Amos B. (1982): The Jonas Martin Era, Denver: The Author.

Hostetler, John (1993): Amish Society, Balitmore: Johns Hopkins.

Kephart, William M./ Zellner, William W. (1994): Extraordinary Groups, New York: St.

Martin's Press.

Lee, Daniel B. (2000): Old Order Mennonites. Rituals, Beliefs, and Community, Needham: Rowan and Littlefield (Burnham).

Lyman, Stanford/ Scott, Marvin (1968): »Accounts«, in: American Sociological Review 33, pp. 46-62.

Luhmann, Niklas (1995a): Soziologische Aufklaerung, Opladen: Westdeutsche.

- (1995b): Social Systems, Palo Alto: Stanford University Press.

- (2002a): Die Religion der Gesellschaft, Frankfurt am Main: Suhrkamp.

- (2002b): Theories of Distinction, Palo Alto: Stanford University Press.

Redekop, Calvin W. (1969): The Old Colony Mennonites, Baltimore: John Hopkins.

Roberts, Keith A. (1990): Religion in Sociological Perspective, Belmont: Wadsworth.

Schneider, Louis (1970): Sociologial Approach to Religion, New York: John Wiley and Sons.

Schütz, Alfred (1967): The Phenomenology of the Social World, Evanston: Northwestern University Press.

Spencer Brown, George (1969): Laws of Form, London: Allen and Unwin.

Weber, Max (1958): The Protestant Ethic and the Spirit of Capitalism, New York: Scribner's Press.

Weber, Max (1963): The Sociology of Religion, Boston: Beacon Press.

Weber, Max (1980): Wirtschaft und Gesellschaft, Tübingen: Mohr Siebeck.

Yinger, Milton (1965): Religion, Society, and the Individual, New York: Macmillan.

Zito, George V. (1983): »A Sociology of Heresy«, in: Sociological Analysis 44, pp. 123-130. 